\title{
AN UPDATE ON IMPERIAL TOPAZ FROM THE CAPÃO MINE, MinAS GERAIS, BRAZIL
}

By Daniel A. Sauer, Alice S. Keller, and Shane F. McClure

The Capão mine is one of the oldest and most productive fully mechanized Imperial topaz mines in the historic Ouro Preto area of Minas Gerais, Brazil. Bulldozers, water cannons, and dragscrapers are used in two main pits to remove the thick brown overburden for processing to recover topaz crystals in a broad range of sizes and colors. The rarest color is pinkish purple to purple. Heat treatment will turn some brownish yellow or orange Imperial topaz to "peach" or pink. Preliminary testing suggests that there may be a difference in fluorescence between heattreated and non-heat-lreated topaz.

\section{ABOUT THE AUTHORS}

Mr. Saver, a gemologist and geologist, is technical director of Amsterdam Sauer Company, Brazil. Ms. Keller is editor of Gems \& Gemology, Gemological institute of America, Santa Monica, California. Mr. McClure is supenvisor of Identification Services at the GIA Gem Trade Laboratory, Carlsbad, California.

Acknowledgments: The authors thank Dr. Wagner Colombarolli, Edmar Evanir da Silva, and Fernando Celso Gonçalves, of the Topázio Imperial Mining Company, for the invitation to visit the mine and for providing information. Constantino Psomopoulos of Amsterdam Sauer Co. selected samples for photograph, reviewed the original paper, and helped with subsequent revisions.

Gems \& Gemology, Vol. 32, No. 4, pp. 232-241. (C) 1996 Gemological Institute of America

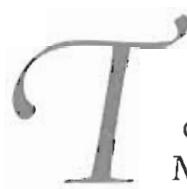

)

opaz has been known from the Ouro Preto area of Minas Gerais for more than 200 years, with the discovery first announced publicly in 1768 (Rolff, 1971). Since then, topaz has been recovered sporadically from a number of deposits within an area of approximately $120 \mathrm{~km}^{2}$ that lies, for the most part, just west of the colonial city of Ouro Preto. Today, the region known in the world gem market as the Ouro Preto Imperial topaz district comprises two major active mining sites - Capão (formerly Capão do Lana) and Vermelhão (also known as Saramenha) - and a few dozen abandoned mines, occurrences, and alluvial workings. Although Vermelhão and other mining areas have yielded excellent gem topaz (Vermelhão is especially noted for the large crystals found there), the only private, wholly owned, and completely mechanized mine currently in full operation is the Capão mine, in the Rodrigo Silva district. Specimens and information about that mine were gathered by the senior author (DAS) during several visits over the last few years and in a visit by the second author (ASK) in August 1996.

Several articles have been written on the intense orangy yellow-to-orange-to-"sherry" red topazes from Ouro Preto (figure 1) that are called Imperial topaz in the trade (e.g., Atkinson, 1908, 1909; Bastos, 1964, 1976; Olsen 1971, 1972; Fleischer, 1972; D'Elboux and Ferreira, 1975, 1978; Keller, 1983; Cassedanne and Sauer, 1987; Cassedanne, 1989). The present article describes the current mining situation at the Capao mine and describes the topaz found there, both as it is recovered and as it reaches the market. It also reports on the heat treatment of some orange Imperial topaz to produce attractive pink stones.

\section{LOCATION AND ACCESS}

Capão is one of several known topaz deposits in the Ouro Preto area (figure 2). It can be visited easily in a day from Rio 
Figure 1. The fine Imperial topazes from the region near Ouro Preto, in Minas Gerais, Brazil, are most commonly intense orangy yellow to orange. The most sought-after Imperial topazes are the "sherry" red and saturated pink stones. Bi-colored stones are rare. The stones shown here range from 8.82 to $14.28 \mathrm{ct}$; the

bi-colored topaz at the bottom is $14.10 \mathrm{ct}$. Stones courtesy of Amsterdam Sauter Co.; photo (C) Harold (4) Erica Van Pelt.

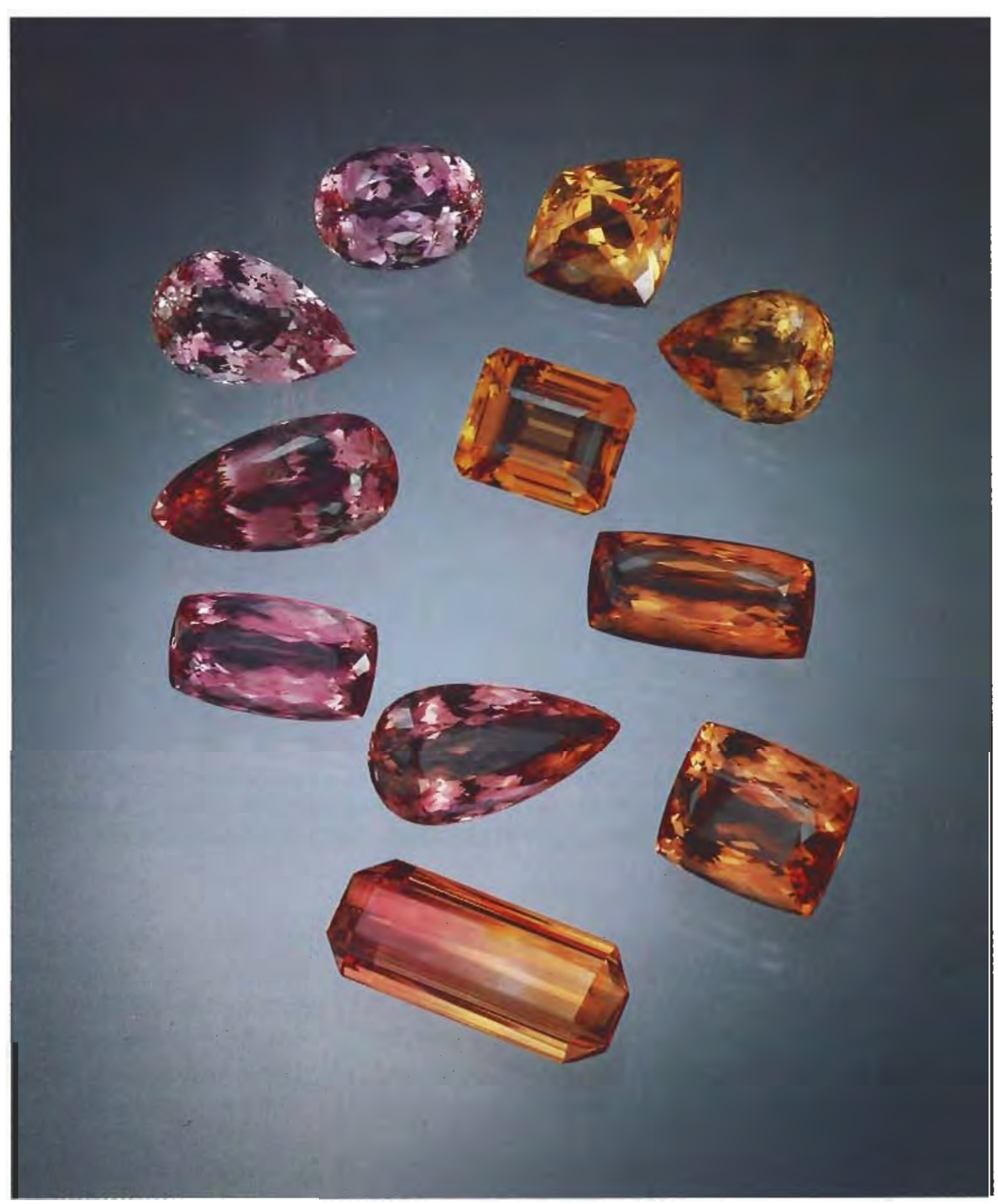

de Janeiro, traveling first by air (about 350 air kilometers) to Belo Horizonte, and then by car on Route BR040 (Belo Horizonte-Rio de Janeiro) south for $30 \mathrm{~km}$ (19 miles) to Route BR356, then east (toward Ouro Preto) for $53 \mathrm{~km}$ (33 miles), at which point a right turn onto a dirt road leads to Rodrigo Silva, about $7 \mathrm{~km}$ to the south. From Rodrigo Silva, a village of approximately 1,200 residents, one travels on a dirt road about $3 \mathrm{~km}$ west to reach the mining site. Access to the mine area is limited to those who work there or are invited by the principals. Located in one of the highest regions of the country, the Capão mine lies at an altitude of about $1,200 \mathrm{~m}(3,900 \mathrm{feet})$. The chief industry in this mountainous area is cattle ranching, both for beef and dairy products.

Since 1972, the mine has been under the ownership of the Topázio Imperial Mining Company (Topázio Imperial Mineração, Comércio e Indústria
Ltda.), of which the three partners are Dr. Wagner Colombarolli, Edmar Evanir da Silva, and Fernando Celso Gonçalves. The entire concession is approximately 600 ha (1,500 acres); it consists of the main mine and three reservoirs. The Topázio Imperial Mining Company also has another concession, the Córrego do Cipó complex, which is $2.5 \mathrm{~km}$ northwest of Capão (again, see figure 2); it is now under development for possible future mining.

\section{A BRIEF SUMMARY OF THE GEOLOGY}

The geology of the Ouro Preto topaz area has been discussed by Keller (1983), Pires et al. (1983), Ferreira (1983 and 1987), Cassedanne and Sauer (1987), Cassedanne (1989), and Hoover (1992). To summarize, the topaz deposits occur in the Ouro Preto quadrangle of the Quadrilátero Ferrífero la famous iron-producing areal in southern Minas Gerais. The topaz mineralization falls within an 


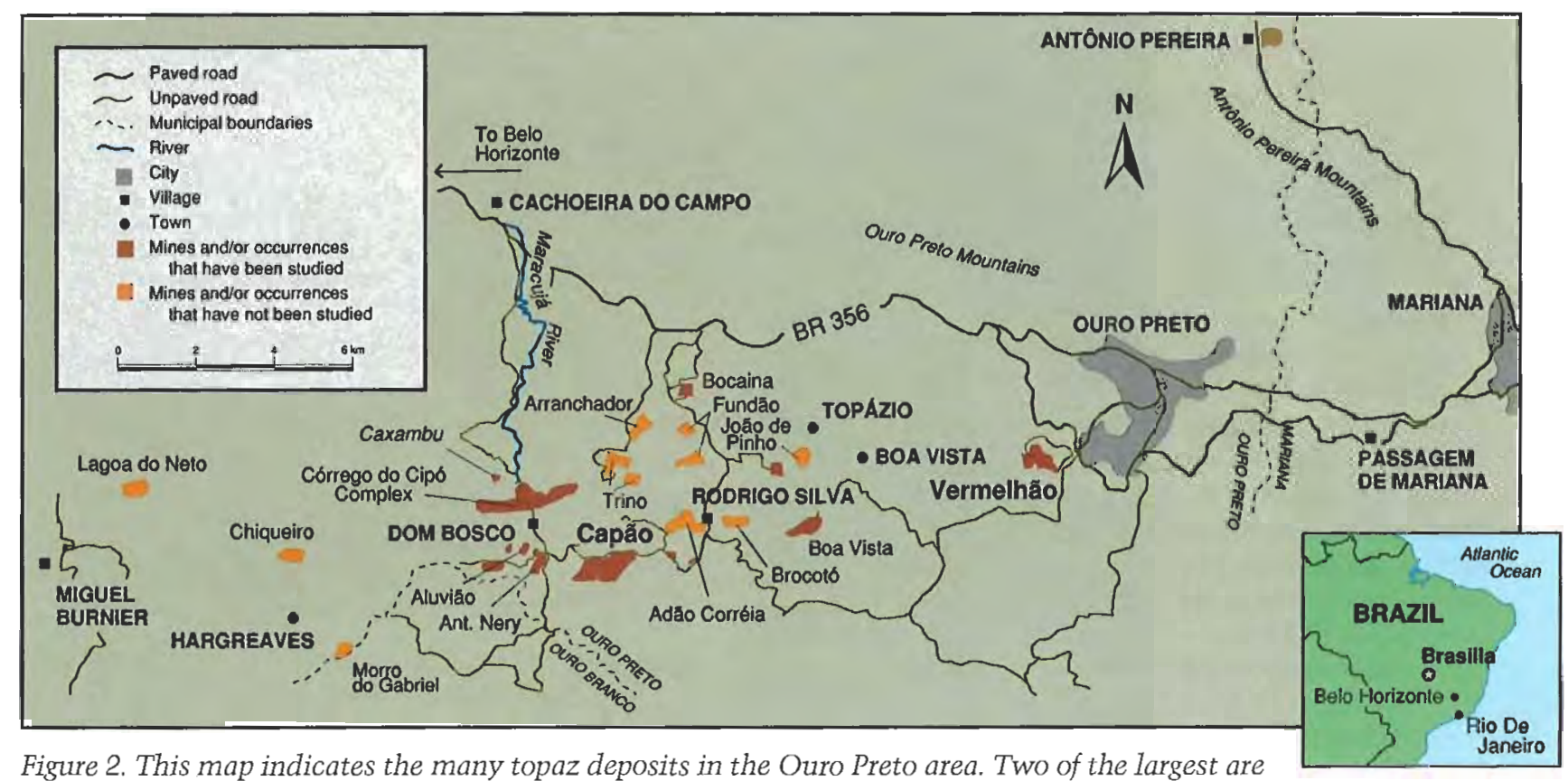

Figure 2. This map indicates the many topaz deposits in the Ouro Preto area. Two of the largest are the Vermelhão mine, near Ouro Preto, and the Capão mine, near the village of Rodrigo Silva. Adapted from a 1987 map produced by the Minas Gerais Light and Power Company.

east-west trending zone that extends from Antônio Pereira village (Antônio Pereira mine) on the east, to Miguel Burnier village (Lagoa do Neto occurrence) on the west, both in the Ouro Preto district (again, see figure 2). Pires et al. (1983) identified four main topaz belts in the region, each of which trends east-west.

The formation of the topaz has been the subject of much debate over the last century (see Olsen, 1971, 1972; Fleischer, 1972; for an informative summary of this debate, see Cassedanne, 1989). The mineralized zone is characterized by intensely weathered (to depths of at least $50 \mathrm{~m}$ ) rocks underlain by unweathered granitic gneisses, granites, and three series of Precambrian metasedimentary rocks. The Minas series of Precambrian metasediments was subjected to two major intrusive events: (1) about 2,700 million years ago, by a batholith that fractured the sedimentary roclss; and (2) about 1,300 million years ago, by acid intrusions (high-silica igneous rocks). It is believed by Keller (1983) and others that one or both of these intrusions provided the mechanism for the fluorine-rich solutions that entered the rocks through fractures and generated the topaz mineralization. Pires et al. (1983), Oliveira (1984), and Hoover (1992) support the formation of strata-bound topaz deposits from a predominantly hydrothermal process that occurred during or shortly after a period of intense metamorphism.

Regardless of its mode of formation, the mineralized rock comprises a single horizon that varies in thickness from 1 to $6 \mathrm{~m}$ (rarely, to $10 \mathrm{~m}$ ). It is composed of a heavily weathered yellowish to dark brown talc-clay rock called "brown terrain" that is cut by discontinuous kaolinite veins (Cassedanne, 1989) and lenses. Topaz crystals are found within the kaolinite-together with quartz, mica, and specular hematite. They sometimes are associated with rutile and, rarely, with green and blue euclase.

\section{CURRENT MINING OPERATION}

At Capão, the mining operation has grown significantly from the single shallow pit last described in this journal by Keller (1983). At the time of the present authors' August 1996 visit, two large open pits were being worked, separated by a narrow access road that will be removed in the near future to malse one large pit. The larger pit was $30 \mathrm{~m}$ at its deepest point and approximately $350 \mathrm{~m}$ long by $150 \mathrm{~m}$ wide (figure 3). The smaller pit was $18 \mathrm{~m}$ at its deepest point, and approximately $200 \mathrm{~m}$ by $80 \mathrm{~m}$ (figure 4). The two pits together covered about 7 ha, or 17 acres.

Capão Creek, which runs through the hilly concession area, has been dammed in three places to form reservoirs that serve the mining operation and minimize its environmental impact. One reservoir, for sedimentation control, blocks off an area where the mine tailings are dumped; once the sediments have settled to the bottom of the reservoir, the suspension-free water is released back into the creek. The other two reservoirs provide water for mining and washing the ore. 
Because of the depth of the current mining operation, dragscrapers are now used at both pits to recover the topaz. Large buckets are dropped from overhead lines into the pit, where they scoop up the materials comprising the weathered zone (figure 5) and drag them to the top for processing. At the time of our visit, there were two dragscrapers at the larger pit and one at the smaller (newer) one. At both pits, bulldozers work the surface of the pit and push the lateritic soil and rock materials into the path of the dragscraper. This material is then pulled to a large, fixed bucket (washing area) at the top of the pit and washed by water cannons to form a mud pulp. This pulp then flows to a fixed screen, with a quarter-inch (less than $1 \mathrm{~cm}$ ) mesh, through which the smaller particles pass to the sedimentation reservoir. The remaining gravels are processed to recover topaz. As a secondary operation, water cannons are used at the bottom of the pit both to soften the rock for recovery by the dragscraper and to create a slurry. The slurry is then pumped out of the pit (again, see figure 3) onto the same quarter-inchmesh fixed screen used to separate the mud pulp.

When the bulldozer uncovers a white kaolinite vein, a good indicator of topaz mineralization, the driver stops. Three people are sent to scrape the vein by hand to look for gem crystals (figure 6). Like all of those who are authorized to pick up crystals, these special miners are identified by their red hats. The remaining minerals recovered from these veins are processed in smaller screens, also with a quarter-inch mesh.

To date, the owners have determined that open-pit mining is the most efficient system for recovery of the topaz. Core drilling has shown that mineralization extends as much as $40-50 \mathrm{~m}$ below the lowest part of the larger pit (W. Colombarolli, pers. comm., 1996). Over the last two yearsbecause of the combined effects of a strong currency / which has more than doubled labor costs in U.S. dollar amounts), the deeper workings, and stricter environmental requirements-operating costs for the Capão mine have risen $70 \%$. The sedimentation reservoir will be full after only about 10 years; it must then be restored to its natural state, and another reservoir created.

Recovery. At the washing area at the top of the pits, giant water cannons first push the material removed by the dragscraper through a 4 inch (10 $\mathrm{cm}$ ) "grizzly" screen (figure 7). Material that does not pass through the screen is rejected. Gravity carries the remaining pulp down through large gutter

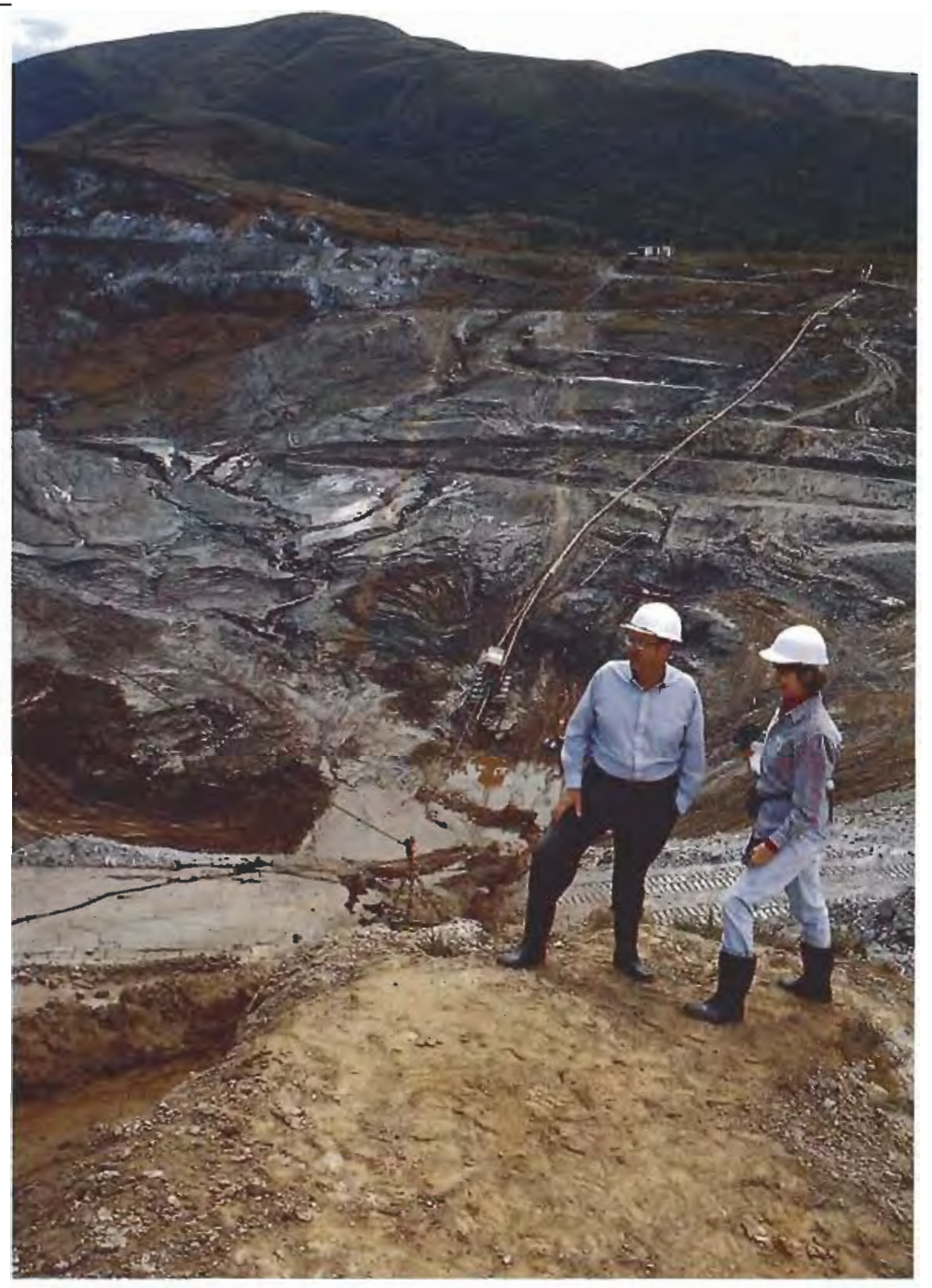

Figure 3. In August 1996, the larger pit at the Capão mine was $30 \mathrm{~m}$ deep and approximately $350 \mathrm{~m}$ long. Toward the bottom of the pit, a water cannon softens the weathered host material and creates a slurry that is then pumped out of the pit. One of the mine owners, Dr. Wagner Colombarolli, is standing at the upper edge of the pit with one of the authors. Photo by Daniel A. Sauer.

pipes to the quarter-inch-mesh screen that separates out the smaller particles. The fraction that remains is washed to remove any residual clay, so only rock fragments and minerals are left for further processing.

Next, a conveyor belt transports the washed material to a bucket wheel that tosses the rock fragments and minerals onto a two-tier vibrating screen: One tier has a $1 \frac{1 / 4}{4}$ inch mesh and the other is $5 / 8$ inch. Any material over $11 / 4$ inch is put in the waste pile. The fractions that remain-one between $1 \frac{11 / 4}{4}$ inch and $5 / 8$ inch and the other less than $5 / 8$ inch-are stockpiled separately into two silos. 


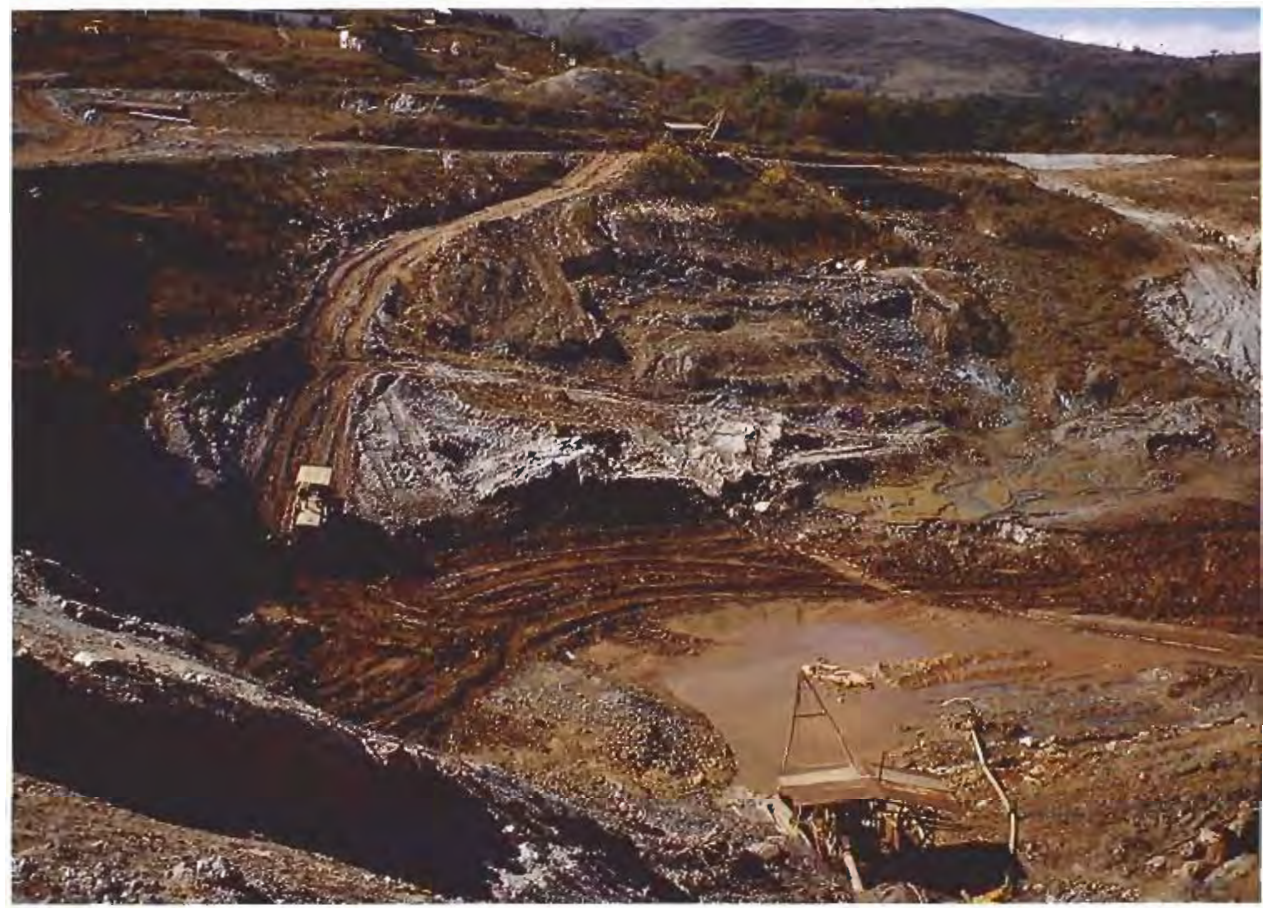

Figure 4. The newer, shallower pit at Capãoseparated from the original pit by only a nar row access road (on the left)-has proved very productive. Here, a bulldozer pushes the intensely weathered rocks and soils into the center of the pit for washing. Photo by Daniel A. Sauer.

For final processing, crystals and rock fragments from one of the silos are placed on another conveyor belt, where several sorters pick out the topaz by hand (figure 8). By only processing one of the two sizes at a time, the miners reduce the risk of larger stones hiding smaller ones. Any topaz found is placed in a tube that runs alongside the conveyor belt. At the end of the day, a security manager runs water through the tube and collects all of the topaz in a bag at one end. These crystals are then placed in a locked box that has a padlock at the bottom and two "blades" at the top, so the crystals can be inserted easily but will not drop out if the box is turned upside down

Currently, approximately 50 people are involved in the Capão mining and processing operation. Because more ore is mined daily than can be processed, some of the screened gravels are stockpiled for processing during the December-to-April rainy season, when mining slows down considerably.

\section{PRODUCTION}

Topaz is found in a broad range of colors at the Capão mine: light yellow, orange-yellow, brownish orange, pinleish orange ("salmon" or "peach"), pink, reddish orange, orange-red, and "sherry" red lagain, see figure 1). All of these colors of topaz from the Ouro Preto deposits are traded as "Imperial."

The rarest color is pinkish purple to purple (figure 9). Although this hue was not seen at the Capão mine for almost eight years, approximately 200 grams were found from a single area of the main pit in 1996. Most of these crystals were heavily included, so the total production is expected to yield no more than 15 carats of faceted stones, ranging from 0.5 to $2 \mathrm{ct}$. Also rare, but seen in finer, less-included, qualities this year, are bi-colored crystals. When cut, these make exquisite gems (again, see figure 1).

After purple, the next rarest color of Imperial topaz is a slightly brownish or "sherry" red. The most sought-after color in the topaz market, "sherry" red topaz represents less than one-half of one percent of the total cuttable material found. Most faceted "sherry" red stones from Capão are 5-10 ct, but 20-30 ct topazes in this color range have been cut. Also rare are the pale-to-saturated pink stones that occur naturally at the Capão mine.

Most common is yellow-to-orange topaz. Capão is the main source for commercial sizes $(2-8 \mathrm{ct})$ in this color range. In addition, many stones in the 10-15 ct range have been cut; $20-30$ ct stones are rare but available.

During our visit to the Capão mine, we were shown a half-day's production from the main pit (figure 10). The $3.5-4 \mathrm{~kg}$ of topaz crystals represented very good output for one day-according to the mine owners, a half-kilo of crystals is typical. The crystals we examined were predominantly yellow to orange to pink, although we did see at least one $5.5 \mathrm{~cm}$ orange-red crystal that would yicld about 12 ct of faceted topaz, with the largest stone 7-8 ct. The largest fine crystal was $8 \mathrm{~cm}$ and was deep red down the c-axis. We also saw a few bi-colored, orange-and-pink, crystals. 
Production from the smaller pit for the same time period was 500-600 grams. We saw more pink stones in this lot than in that from the larger pit.

Only $1 \%-2 \%$ of all the material recovered is faceting quality, according to Dr. Colombarolli. In 1995 , from an average of $11,000 \mathrm{~m}^{3}$ of ore processed every month, fewer than $100 \mathrm{~kg}$ of mine-run topaz crystals were recovered. The estimated yield from these crystals, based on experience to date, would be 5,500 carats-a total of 66,000 carats of cut Imperial topaz for the year, or $0.5 \mathrm{ct}$ of topaz per cubic meter of ore processed.

The largest crystal recovered to date at the Capão mine (although broken into four pieces) was $1.3 \mathrm{~kg}$, Dr. Colombarolli noted.

\section{HEAT TREATMENT}

Although "peach" to pink (figure 11) Imperial topaz does occur naturally, these colors may be produced in some brownish yellow or orange topaz by heat treatment, which removes the yellow color center. At one operation visited by the second author [ASK], the cut stones are put in a small (about 7.5 $\mathrm{cm}$ square) clay tray that is then placed in an oven, and the temperature is brought to $1050^{\circ} \mathrm{F}\left(565^{\circ} \mathrm{C}\right.$; it takes approximately 40 minutes). The oven is then turned off, and the stones are allowed to cool slowly to room temperature, to avoid thermal shock, before they are removed. Although the occasional "peach" stone that results from a partial heating may turn pink on further heating, the pink color obtained at $1050^{\circ} \mathrm{F}$ is usually the best that can be achieved. Reheating a pink stone or heating it

Figure 5. One of two dragscrapers in the larger pit at Capão pulls the saturated, intensely weathered host material to the top for processing. Photo by Daniel A. Sauer.

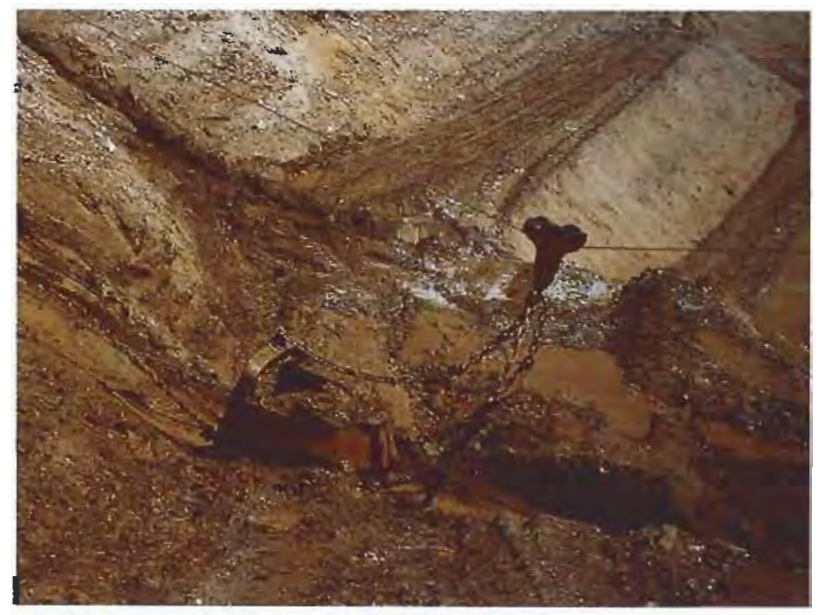

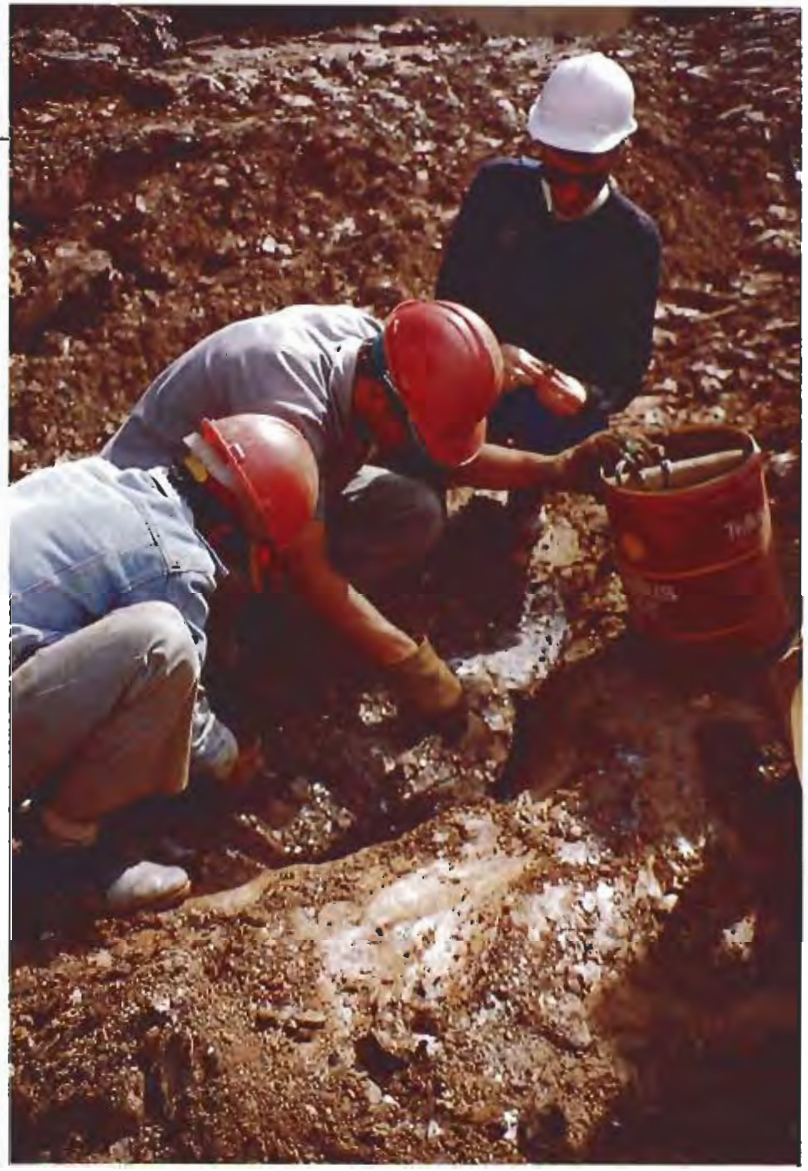

Figure 6. When the bulldozer uncovers a distinctive kaolinite vein, all other activity stops. Certain miners (denoted by red hats) then search for topaz crystals by hand. Here, the senior author examines a topaz crystal found in this thin white vein. Photo by Alice S. Keller.

longer will not produce any additional change (see also Nassau, 1994). However, as shown in figure 12 , the change is often substantial.

Most topaz is not suitable for heating, because topaz typically contains a number of inclusions: liquid-and-gas, breadcrumb-like crystal clusters, needle-like voids, transparent-to-translucent rhombohedral crystals or negative crystals, and fingerprint-like patterns of liquid inclusions. When liquid inclusions, in particular, are present, there is a good chance that the stone will develop large cracks or localized fractures as a result of fluid expansion.

\section{GEMOLOGICAL TESTING}

Materials and Methods. We examined a small sample of material that the Amsterdam Sauer Company had obtained directly from the Capão mine office during the last two years and cut in their own facilities. The sample included: five faceted naturalcolor Imperial topazes, ranging from brownish yellowish orange to pinkish orange $(3.09-9.59 \mathrm{ct})$; two faceted stones $(0.65$ and $1.19 \mathrm{ct})$ and three crystals $(17.73-67.97 \mathrm{ct})$ that were pinkish purple; six faceted 


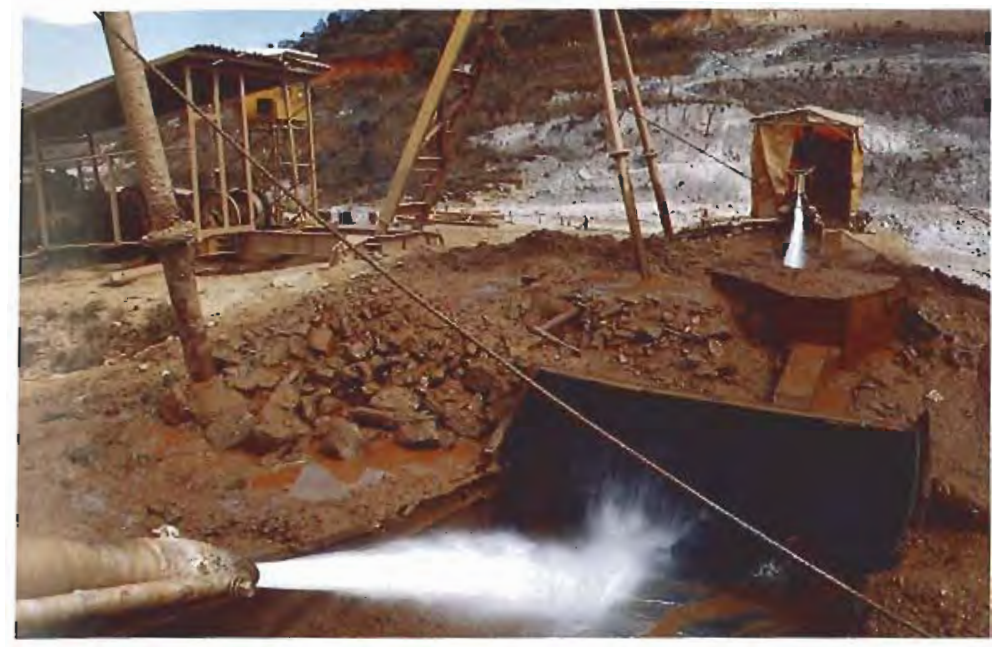

Figure 7. The two dragscrapers bring the host material directly to corresponding platforms at the top of the larger pit, where miners wield large water cannons to wash off the finer particles and push the rock fragments through a series of grates. The largest rocks are screened out first. Photo by Daniel A. Sauer.

stones that had been heat treated to purplish pink (0.90-2.61 ct); and one yellowish orange crystal $(97.59 \mathrm{ct})$ that had been sawn in half, with one half then heat treated to purplish pink. All of the heattreated stones had been treated by the method described in the preceding section.

Refractive index readings were obtained on all of the cut stones with a Duplex II refractometer and a near-sodium equivalent light source. Specific gravity on the cut stones was determined by the hydrostatic weighing method, with three separate measurements taken on each stone. A desk-model Beck prism spectroscope was used to examine the absorption spectra of the cut stones in the study, and a polarizing-filter dichroscope was used to determine the pleochroism on all samples. The ultraviolet fluorescence of all samples was viewed in a darkened environment using four-watt longand short-wave lamps. The stability to light of two of the heat-treated purplish pink samples and two of the natural-color orange samples was tested with an Oriel 300-watt solar simulator. The four stones were placed in the solar simulator for 145 hours, which is equal to about 290 hours of sun exposure (at noon strength for a mid-latitude location). The temperature was monitored so that it did not exceed $130^{\circ} \mathrm{F}\left(54^{\circ} \mathrm{C}\right)$. Halfway through the test, and at the end, we compared the samples to the other, comparable-color stones in this study.

\section{DESCRIPTION OF THE TOPAZ}

We determined refractive indices of $\mathrm{n}_{\alpha}=1.630$ and $\mathrm{n}_{\gamma}=1.638$ (birefringence $=0.008$ ) on all of our samples and a specific gravity of $3.52-3.54 \pm 0.02$. These findings are consistent with published values for topaz (see, e.g., Webster, 1994) and did not vary for any of the colors we examined, including those that were the result of heat treatment.

Also consistent with published values are the absorption spectra and pleochroism. In most stones, the only absorption visible was a general darkening of the far red portion of the spectrum. When viewed down the c-axis, the heated pink stones and the pinkish purple crystals showed a barely discernible line at $682 \mathrm{~nm}$. This line is related to the chromium that produces these colors; it has previously been

Figure 8. In a shed-like structure behind the main pit, miners manually sort through the concentrate, searching for topaz. Any topaz found is placed in tubes along either side of the conveyor belt. Photo by Daniel A. Sauer.

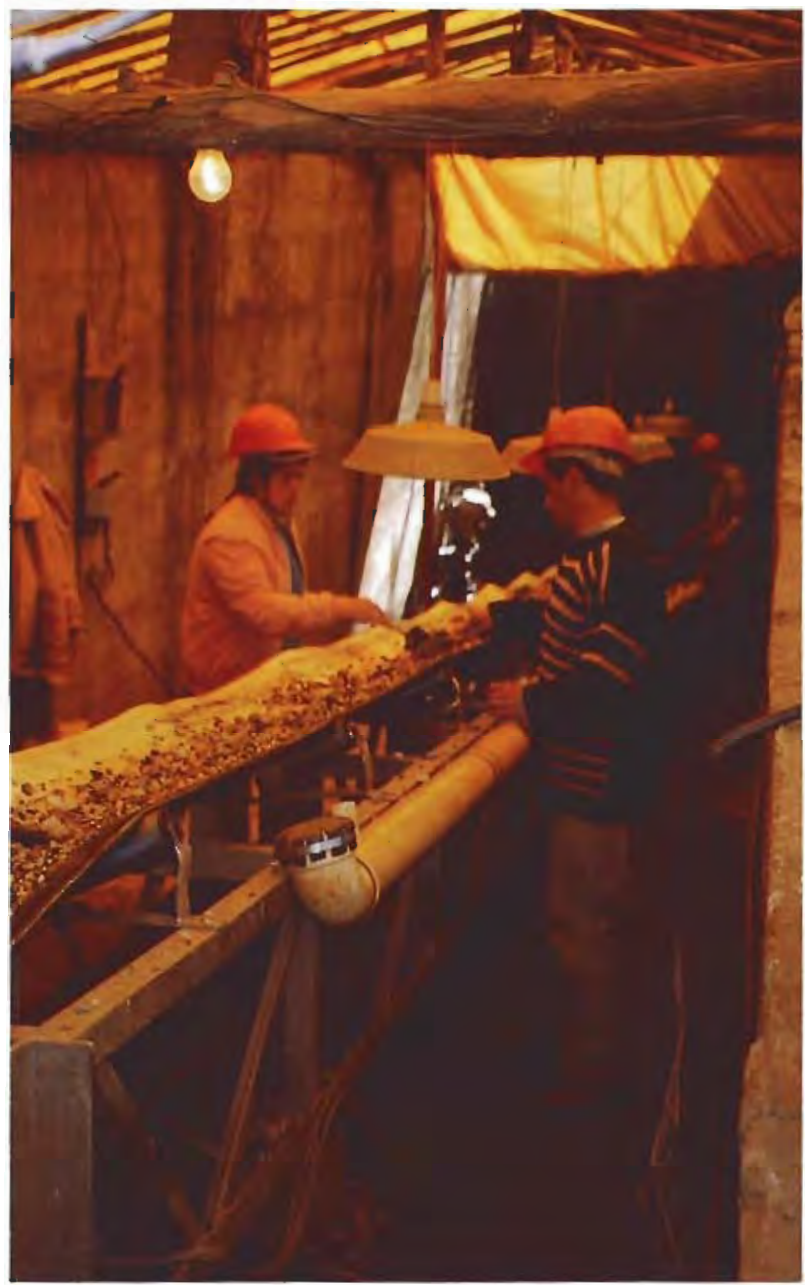


reported in heat-treated pink topaz from Brazil and in natural-color pink topaz from Pakistan (Hoover, 1992; Webster, 1994).

The pleochroism of the predominantly orange material was yellow, yellowish orange, and purplish pink. This changed to shades of pink in two directions, and colorless in the third, after heat treatment. Pleochroism in the pinkish purple samples was purplish pink, pinkish purple, and colorless.

All of the samples were inert or fluoresced moderate orange to long-wave ultraviolet radiation, with a somewhat stronger reaction in the predominantly orange stones. To short-wave UV, the orange and pinkish purple stones fluoresced a very weak to moderate chalky yellow-green. However, the heattreated pink topazes had a generally stronger fluorescence than the natural-color stones, with a shift in fluorescence hue to a yellowish or greenish white (figure 13). This distinction between the heated and unheated topazes was very evident in the two halves of the sawn topaz crystal (figure 14). To the best of our knowledge, this difference in fluorescence has not been reported previously in the literature. However, our results are based on a small sample and so are only preliminary. The possibility of fluorescence as an indicator of treated or natural color needs to be investigated further with a significant sample of known natural-color pink topazes.

It is interesting that although the internal characteristics of the stones we examined were typical of topaz from this area (liquid inclusions, groups of tiny crystals, some larger rhombic crystals, angular grain plains, and internal fractures), there was no apparent difference in the nature of these inclusions between the heated and unheated stones. This was true even for the sawn crystal (figure 15), which was heavily included; we thought it likely that at least some of the liquid inclusions in such a crystal would have burst. Nevertheless, we caution against heating material that has inclusions, as such stones often do not survive the treatment process.

There was no noticeable loss or change of color in any of the topazes tested with the solar simulator, either the heat-treated purplish pink or the natural-color orange stones.

\section{CUTTING}

Because topaz has perfect basal cleavage, the table must always be polished at an angle to the c-axis $\left(12^{\circ}-15^{\circ}\right.$, according to Webster, 1994); extreme care should be taken to avoid grinding the stone perpendicular to the cleavage plane. Also, inclusions can cause the stone to break on the wheel. At

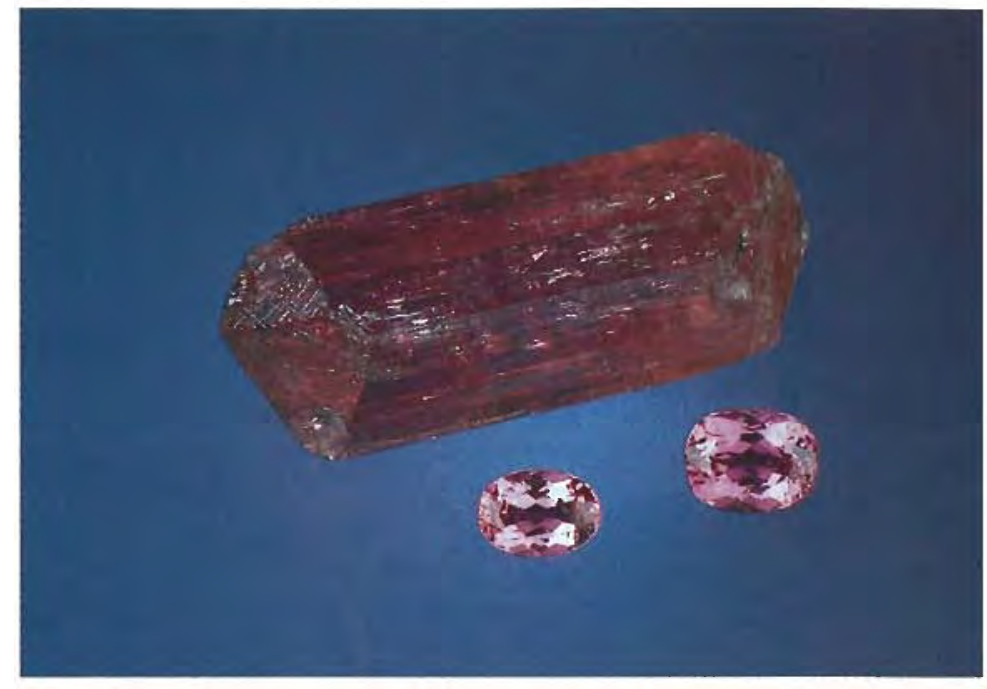

Figure 9. One of the rarest colors of topaz from the Ouro Preto region are these pinkish purple gems, found in a small area of the Capão mine. This crystal is $36.87 \mathrm{ct}$; the cut stones are 1.19 and $0.65 \mathrm{ct}$. Photo by Shane F. McClure.

Amsterdam Sauer, topaz cutters use a 360 grit grinding wheel, a 600 grit faceting disk, and polish the stones on a lead/tin lap with Linde $\mathrm{A}\left(\mathrm{Al}_{2} \mathrm{O}_{3}\right)$ powder. Recovery depends on the amount of inclu-

Figure 10. For the authors, the mine owners removed the topaz crystals recovered after only about a half-day's work (usually, they are recovered only once a day). The 3.5-4 kg of topaz crystals shown here represent a particularly good yield for a single day from the larger pit. The largest crystal, in the foreground, is approximately $8 \mathrm{~cm}$ long. Photo by Daniel A Sauer.

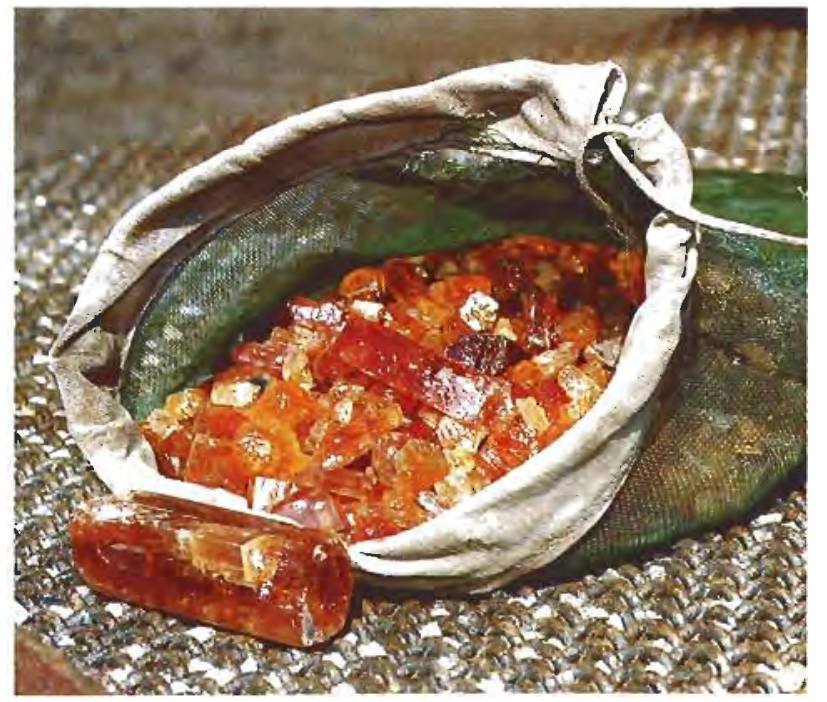




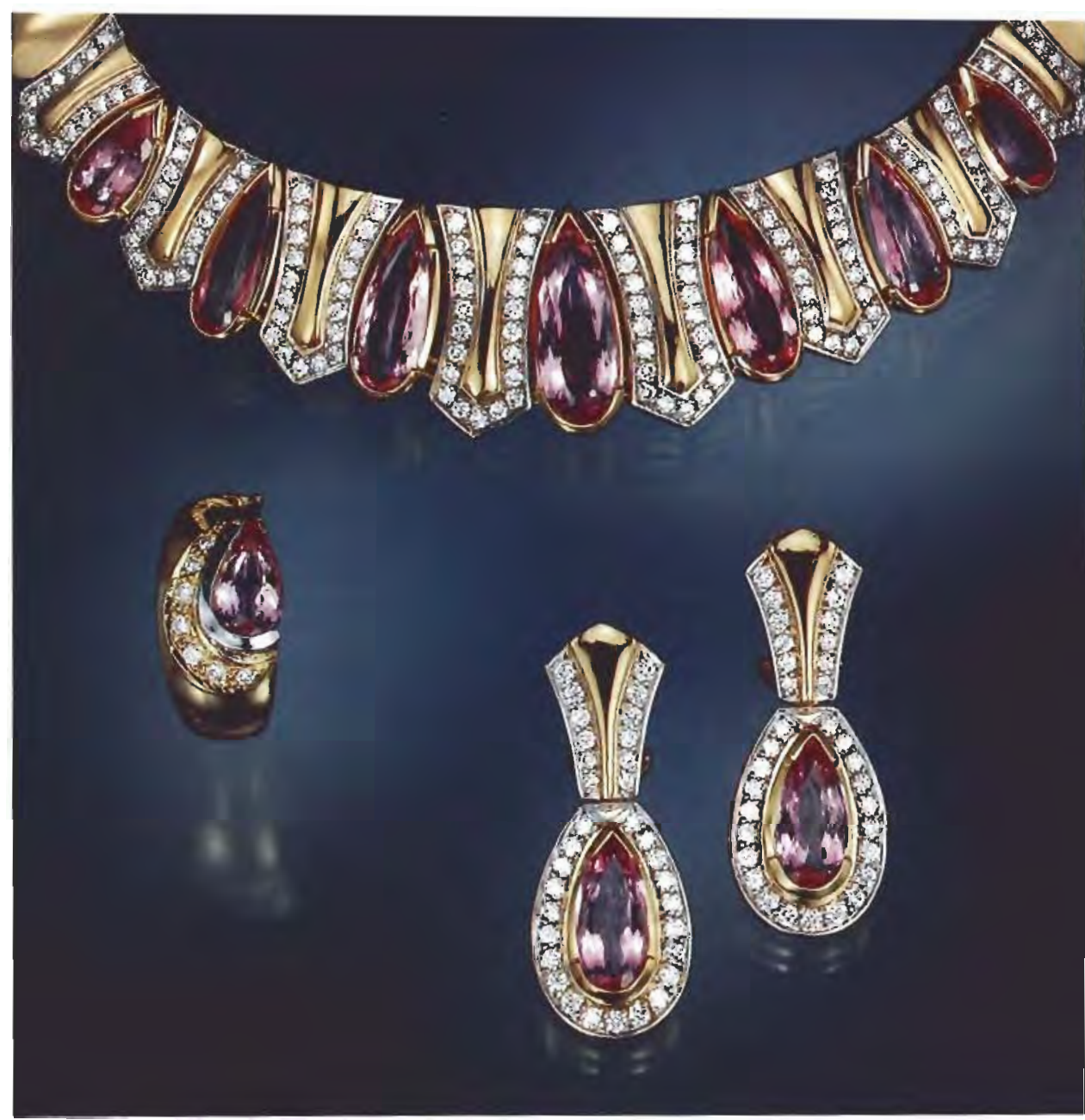

Figure 11. This suite of jewelry is composed entirely of pink topazes from Ouro Preto. They represent some of the superb stones from this historic Imperial topaz locality. The topazes in the necklace weigh a total of 30.36 $\mathrm{ct}$; those in the earrings, $5.50 \mathrm{ct}$; and the one in the ring is $1.90 \mathrm{ct}$. Jewelry courtesy of Amsterdam Sauer Co.; photo $\mathbb{C}$ Harold (4) Erica Van Pelt.

sions in each crystal. Well-formed, fairly clean crystals yield up to 2 carats per gram.

\section{SUMMARY AND CONCLUSIONS}

Brazil's historic Ouro Preto topaz region continues to produce significant amounts of fine topaz in a broad variety of colors, which are known in the trade as Imperial topaz. The only private, wholly owned,

Figure 12. This $97.59 \mathrm{ct}$ Imperial topaz crystal was sawn in half and the bottom was heated to $1050^{\circ} \mathrm{F}$, which produced the purplish pink color. Photo by Shane F. McClure.

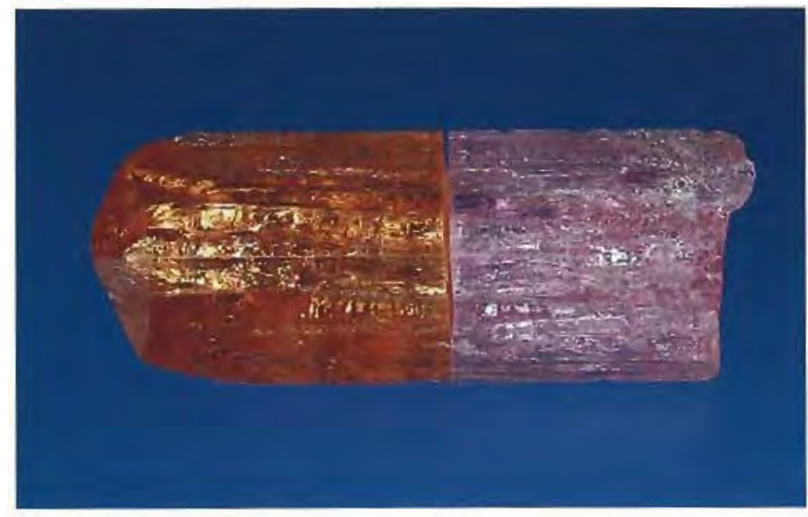

mechanized mine currently in operation there is the Capão mine, which is near the village of Rodrigo Silva. Today, production from this mine represents as much as $50 \%$ of the total production of Imperial topaz from Ouro Preto. Although large amounts of ore are mined from the two open pits that constitute the Capão mine today, the recovery is only $0.5 \mathrm{ct}$ of cut topaz per cubic meter of ore processed. Environmental responsibility and the greater depths

Figure 13. A difference in short-wave UV fluorescence was noted between the unheated and heattreated faceted topazes examined for this study: here, a weak chalky yellow-green in the two unheated pinkish purple stones (left), as compared to moderate to strong greenish-to-yellowish white in the heat-treated pink stones (right). Photo by Shane F. McClure.

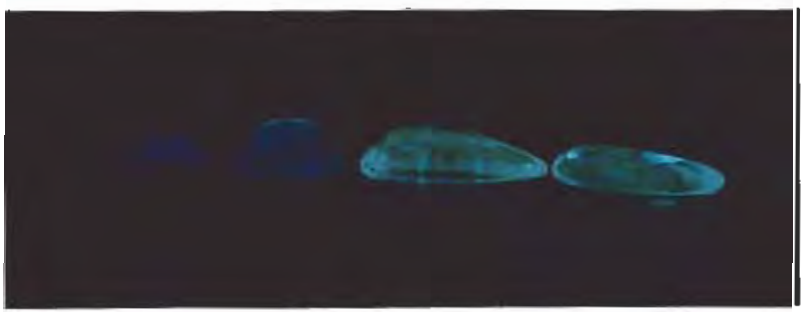




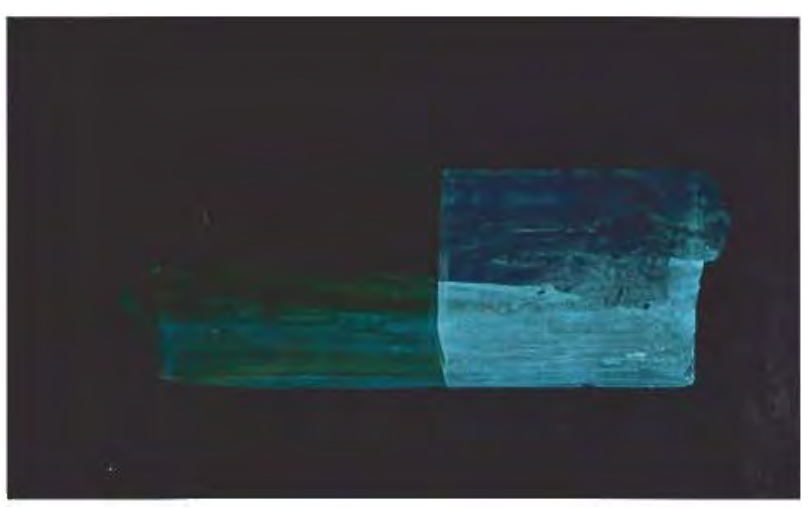

Figure 14. Fluorescence to short-wave UV radiation was the only difference in gemological properties between the unheated (left) and heated halves of the crystal in figure 12. Photo by Shane F. McClure.

of the mining operation, together with the strong currency, have significantly increased the costs of extracting the topaz.

The rarest topaz color is purple. "Sherry" red and bi-colored stones are also uncommon. Certain brownish yellow or orange stones can be heat treated to pink, which is stable to light and heat (as evidenced by the fact that further heating or heating at higher temperatures will not change the color). The preliminary observation that heat-treated pink topaz fluoresces a strong yellowish-to-greenish white to short-wave UV radiation, as compared to the weak to moderate chalky yellow-green of their naturalcolor orange or purple counterparts, deserves further

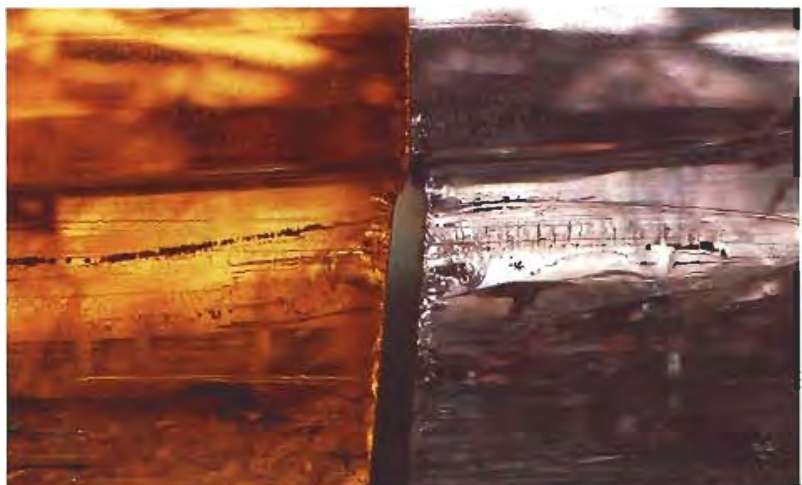

Figure 15. No difference was observed in the nature of the inclusions between the heated and unheated halves of the sawn crystal. Note the undisturbed liquid inclusion plane in the center of the photograph, where it crosses the saw cut. Photomicrograph by Shane F. McClure; magnified 20x.

investigation to determine its usefulness as an identification criterion.

Because of the heavily weathered host rocks and the discontinuity of the gem-bearing veins, open-pit mining appears to be the most efficient means to recover these rare gems. The prospects for continued production at the Capão mine are good, inasmuch as core drilling has shown topaz mineralization as deep as $50 \mathrm{~m}$ below the current low point of the main pit. However, we do not know what impact the difficulties and related costs of extracting the ore at such depths will have on the general availability of this gem material.

\section{REFERENCES}

Atkinson A.S. (1908) Report on topaz in Brazil. Minerals Yearbook, U.S. Bureau of Mines, p. 842.

Atkinson A.S. (1909) Mining for gems in Brazil. Engineering and Mining Journal, June 19, pp. 1234-1235.

Bastos F.M. (1964) The topaz mines of Ouro Preto. Lapidary Tournal, Vol. 18, pp. 918-920.

Bastos F.M. (1976) Imperial topaz from Brazil. Lapidary Joumal, Vol. 30, pp. 1838-1840.

Cassedanne J.P., Sauer D.A. (1987) La topaze impériale. Revue de Gemmologie, No. 91, pp. 2-9.

Cassedanne J.P. (1989) Famous mineral localities: The Ouro Preto topaz mines. Mineralogical Record, Vol. 20, pp. 221-233

D'Elboux C.V., Ferreira C.M. (1975) Topazio na região de Ouro Preto. Boletim do Departemento de Geologia, UFOP, Publicaçāo Especial No. 1, pp. 73-79.

D'Elboux C.V., Ferreira C.M. (1978) Topazio na região de Ouro Preto. Sociedade de Intercambio Cultural e Estudos Geologicos, Semanas de Estudos, Nos. 14 and 15, pp. 14-52.

Ferreira .C.M. (1983) Vulcanismo ácido no quadrilátero ferrifero e sua relação com algumas ocorrências e/ou depósitos minerais. Anais do II Simpósio de Geologia de Minas Gerais, Belo Horizonte, Brazil, pp. 128-133.

Ferreira C.M. (1987) Geologia da jazida de topázio do Morro de Saramenha. Revista Escola de Minas, Vol. 40, No. 3, pp. 15-17.

Fleischer R. (1972) Origin of topaz deposits near Ouro Preto,
Minas Gerais, Brazil, discussion. Economic Geology, Vol. 67, No. 1, pp. 119-120.

Hoover D.B. (1992) Topaz. Butterworth-Heinemann, Oxford, England.

Keller P.C. (1983) The Capão topaz deposit, Ouro Preto, Minas Gerais, Brazil. Gems e) Gemology, Vol. 19, No. 1, pp. 12-20.

Nassau K. (1994) Gemstone Enhancement, 2nd ed. ButterworthHeinemann Ltd., Oxford, England.

Oliveira C.M.M. de (1984) Composição mineralógica e química do nível topazífero nas proximades de Rodrigo Silva (Ouro Preto, Minas Gerais). Resumos, Breves Comunicações, Cursos, Excursões e Mesas Redondas, 33rd Congress of Brazilian Geology, Rio de Janeiro, pp. 265-266.

Olsen D.R. (1971) Origin of topaz deposits near Ouro Preto, Minas Gerais, Brazil. Economic Geology, Vol. 66, No. 4, pp. 627-631.

Olsen D.R. (1972) Origin of topaz deposits near Ouro Preto, Minas Gerais, Brazil, a reply. Economic Geology, Vol. 67, No. 1, pp. 120-121.

Pires F.R.M., Freitas C.O., Palermo N., Sarciá M.N.G. (1983) Geologia e gênese dos depósitos de topázio do distrito de Ouro Preto, Minas Gerais. Anais do II Simpósio de Geologia de Minas Gerais. Belo Horizonte, pp. 283-296.

Rolff A. (1971) Brazilian imperial topaz. Lapidary fournal, Vol. 25, pp. I556-1562.

Webster R. (1994) Gems, 5th ed. Rev. by P. G. Read, Butterworth-Heinemann Ltd., Oxford, England. 